\title{
Gestational Alcohol Exposure Altered DNA Methylation Status in the Developing Fetus
}

\author{
Chanchal Mandal ${ }^{1}$, Debasish Halder ${ }^{1}$, Kyoung Hwa Jung ${ }^{1,2}$ and Young Gyu Chai ${ }^{1,3, *}$ \\ 1 Department of Molecular and Life Science, Hanyang University, 15588 Ansan, Korea; \\ chanchalbge@gmail.com (C.M.); deba_genetic@yahoo.com (D.H.); khjung2@gmail.com (K.H.J.) \\ 2 Institute of Natural Science and Technology, Hanyang University, 15588 Ansan, Korea \\ 3 Department of Bionanotechnology, Hanyang University, 04763 Seoul, Korea \\ * Correspondence: ygchai@hanyang.ac.kr; Tel.: +82-31-400-5513; Fax: +82-31-436-8173
}

Received: 8 June 2017; Accepted: 26 June 2017; Published: 28 June 2017

\begin{abstract}
Ethanol is well known as a teratogenic factor that is capable of inducing a wide range of developmental abnormalities if the developing fetus is exposed to it. Duration and dose are the critical parameters of exposure that affect teratogenic variation to the developing fetus. It is suggested that ethanol interferes with epigenetic processes especially DNA methylation. We aimed to organize all of the available information on the alteration of DNA methylation by ethanol in utero. Thus, we have summarized all published information regarding alcohol-mediated alterations in DNA methylation during gestation. We tried to arrange information in a way that anyone can easily find the alcohol exposure time, doses, sampling time, and major changes in genomic level. Manuscript texts will also represent the correlation between ethanol metabolites and subsequent changes in methylome patterns. We hope that this review will help future researchers to further examine the issues associated with ethanol exposure.
\end{abstract}

Keywords: alcohol; epigenetics; DNA methylation; FASD; fetal development

\section{Introduction}

It has long been believed that the ingestion of alcohol during pregnancy can lead to the birth of infants with developmental defects. The forms of abnormalities resulting from ethanol exposure vary depending on the dose, duration, and frequency of consumption during the gestational period. Maternal genetics and metabolism are also important factors. Alcohol is well known as a teratogenic agent that affects the normal development of a developing embryo. Fetal alcohol spectrum disorder (FASD) is the term commonly used to denote alcohol-related neonatal abnormalities [1,2]. The most severe form of FASD is known as fetal alcohol syndrome (FAS), and manifests as growth retardation, facial abnormalities, and central nervous system (CNS) deficiencies [3,4]. There is no specific time point during gestation when alcohol exposure is not accompanied by harmful consequences. However, the most severe birth defects are correlated with alcohol exposure during the embryonic stage rather than later fetal stages [5]. FAS and other alcohol-related birth defects are examples of what can happen when a mother ingests alcohol during her pregnancy [6]. Many previous studies have described genetic susceptibilities to alcohol-mediated defects. Microarray analysis and next-generation sequencing techniques have found that many developmental genes are altered by in utero alcohol exposure [1-4,7-10]. However, the underlying causes of these alcohol-mediated disorders remain unclear. A combination of genomic, genetic, and epigenetic alcohol research could reveal the molecular mechanisms of these disorders, adding to the utility of investigating the epigenetic and genetic factors involved in ethanol-mediated birth defects.

Epigenetics is the study of changes in gene expression that do not involve changes to the underlying DNA sequence. These changes affect cells' phenotypic expression by regulating relative 
gene expression levels [11]. Epigenetic effects are a common and natural process in living cells, and they occur under tightly controlled and pre-programmed mechanisms. Epigenetics can also be influenced by factors including environmental conditions, age, lifestyle, exposure to toxicants, and disease state. Epigenetic changes are usually non-inherited, but it may be possible to pass down epigenetic changes to offspring if the changes occur in sperm or egg cells. Most epigenetic changes occurring in sperm and egg cells are deleted when the cells combine to form a zygote. Epigenetic regulations are mediated through DNA methylation, histone modification, and non-coding RNA (ncRNA)-associated gene silencing [12-14]. DNA methylation occurs via the covalent addition of a methyl group $\left(\mathrm{CH}_{3}\right)$ at the 5 -carbon of the cytosine ring, resulting in 5-methylcytosine $(5-\mathrm{mC})$ and altering transcription. Most DNA methylation occurs at the CpG site, where a cytosine nucleotide is located next to a guanidine nucleotide. When a methylated CpG island is found in the promoter region of a gene, the expression of that gene is repressed. DNA methylation is performed by a family of methyltransferase enzymes called DNA methyltransferases (DNMTs). In mammalian cells, DNMTs are divided into two major families: maintenance methyltransferase (DNMT1) and de novo methyltransferases (DNMT3A, DNMT3B, and DNMT3L). DNMT2 also displays weak methyltransferase activity [15]. A schematic representation of the DNA methylation process is presented in Figure 1.
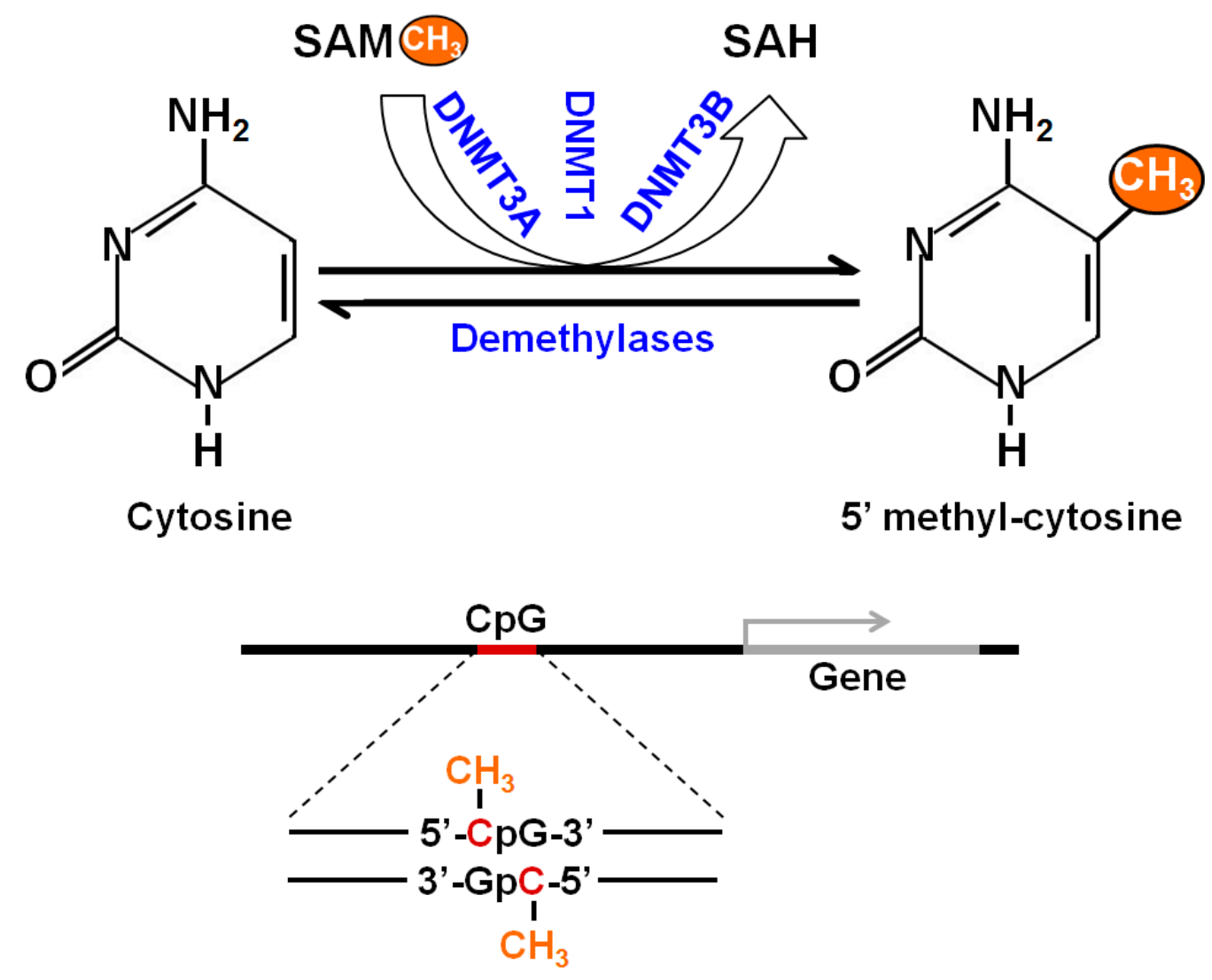

Figure 1. Schematic representation of DNA methylation. The process starts with the covalent addition of a methyl group to form 5-methylcytosine $(5-\mathrm{mC})$. This process is catalyzed by a family of DNA methyltransferases (DNMTs) - DNMT1, DNMT3A and DNMT3B. The majority of DNA methylation usually occurs at $\mathrm{CpG}$ sites and $\mathrm{CpG}$ islands nearby a gene to regulate related gene expression. DNA methylation is an epigenetic mechanism and required fine tuning for proper regulation. 
DNA methylation is associated with imprinting, fate specification and cellular differentiation $[16,17]$. DNA methylation is involved to regulate gene expressions in a genomic context-dependent manner. Briefly, DNA methylation causes transcriptional repression when located within gene promoters. However, when sites are located within gene bodies and intergenic regions, it acts differently [18]. The exposure of cells to any toxicant may cause positive or negative effects. Developing and differentiating cells are more vulnerable to these effects than adult cells. A developing fetus experiences a high level of exposure because its entire body is under development during the embryonic stage. DNA methylation is amenable to environmental factors which can be passed through cell divisions and may persist throughout the entire lifetime [19]. Thus, it is assumed that ethanol exposure may cause epigenetic changes in the developing cells of the fetus. It is evidenced that DNA methylation has a potential role in the etiology of the neurobiological problems found in children with FASD and indicate a valuable epigenetic signature. The type and extent of the epigenetic changes caused by ethanol is a topic of current research. Future studies will reveal the underlying epigenetic mechanisms of ethanol exposure. In this review, we attempted to collect all available information on in utero ethanol exposure and the subsequent alterations in DNA methylation patterns. We hope that our efforts will help future researchers by offering a survey of epigenetic mechanisms under ethanol teratogenicity.

\section{Metabolites of Ethanol and Proposed DNA Methylation Schemes}

Metabolic enzymes are involved in epigenetic mechanisms. Thus, the transcriptional regulation of rate-limiting metabolic enzymes is important for controlling metabolic changes in cells. Levels of metabolites (e.g., acetyl-CoA, s-adenosyl methionine (SAM)) and metabolic hormones contribute to the regulation of gene expression. The activities of major enzymes involved in epigenetic modifications are partially regulated by the concentrations of available substrates and co-factors [20]. Thus, cellular metabolites are involved in the transcriptional regulation of genes, as well as epigenetic mechanisms. It was previously found that prenatal alcohol exposure affects one carbon metabolism and regulates functional gene expressions [21].

Lipotropes are dietary methyl donors that play important roles in metabolism. Dietary lipotropes influence the availability of SAM and, consequently, may influence genomic DNA methylation patterns and the relative expression of nearby genes. Chronic alcoholics are known to suffer from malnutrition [22], and this lack of nutrients could affect SAM production, leading to alterations in DNA methylation patterns. In chronic alcoholics, serum folate levels are significantly reduced compared with non-alcoholics [23]. The demand of folic acid dramatically increased during pregnancy period to meet the requirement for fetal DNA synthesis and proliferation. Maternal alcohol intake reduces the serum folate level in the pregnant mother blood [24]. One of the main reasons to decrease maternal folate level is that ethanol reduces intestinal uptake of dietary folate [25]. The reduction of maternal folate level may cause poor transfer of folate molecules to fetal circulation and creates a slower production of SAM. Recently it was published that chronic alcohol exposure decreased folic acid transport to fetus in human model [26]. Chronic ethanol-exposed primary trophoblasts and BeWo cells showed reduction in mRNA expression of folate binding and transport proteins, including folate receptor $\alpha$ $(F R \alpha)$ and reduced folate carrier (RFC), respectively [25,27]. They also mentioned the possibility of affecting membrane permeability properties that permits poor transportation. A schematic diagram is presented in Figure 2 showing the folate transportation mechanism under ethanol exposed condition. 


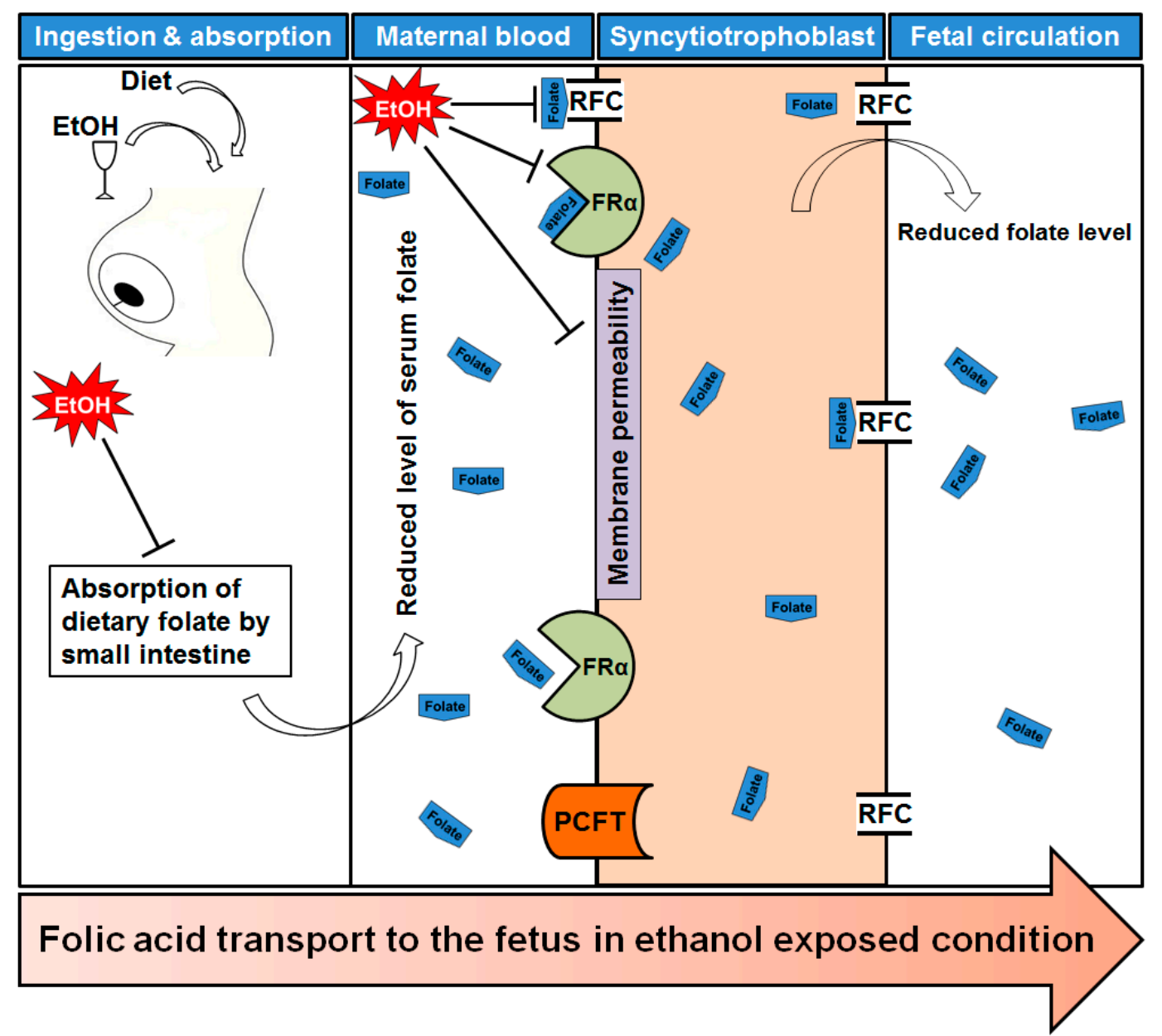

Figure 2. Folate transportation mechanism under ethanol exposed condition. After ingestion of alcohol it is readily absorbed through stomach and intestine. Maternal dietary folate absorption by small intestine is reduced by ethanol intake. As a result, maternal serum folate level is also affected. Transport of folates across the placental membrane is accomplished by placental folate receptors, folate receptor $\alpha$ $(\mathrm{FR} \alpha)$ at the syncytiotrophoblast membrane. The reduced folate carrier (RFC) and the proton-coupled folate transporter (PCFT) are also involved in folate uptake in placenta. Ethanol exposure reduced the expression of FR $\alpha$ and RFC, and caused a significant reduction in receptor activity. Finally, there are low levels of folate in fetal circulation which may offer a reduced methylation of DNA.

Many studies have shown that folate deficiency reduces SAM levels and the SAM to S-adenosyl homocysteine (SAH) ratio and increases $\mathrm{SAH}$ concentrations by inactivating methionine synthase (MS) and methionine adenyltransferase (MAT) [28-30]. Elevated SAH concentration and ethanol itself inhibit DNMTs not to methylate DNA [31,32]. As a result it hampers DNA methylation process and causes hypomethylation. Another major candidate, glutathione (GSH) is connected to the methionine-homocystine pathway. GSH is produced from homocysteine through the transsulfuration pathway. The resulted GSH is further converted to its oxidized form, glutathione disulfide (GSSG). The ratio of GSH/GSSG is maintained by the activity of the glutathione reductase (GR) enzyme [33]. It was reported that ethanol exposure depleted the GSH level and that depletion could influence new GSH formation from homocysteine to recover the deficiency [34]. This phenomenon shifts the reactions from producing methionine and SAM to GSH production. As a result, overall reduction of DNA methylation occurred. Ethanol-mediated depletion of GSH is thought to be mediated by reactive oxygen species (ROS) because, with excessive ROS, the level of GSH was found to be depleted [35]. A schematic representation of ethanol's effect on one carbon metabolism is summarized in Figure 3. 
Correlation between alcohol, homocysteine metabolism and DNA methylation

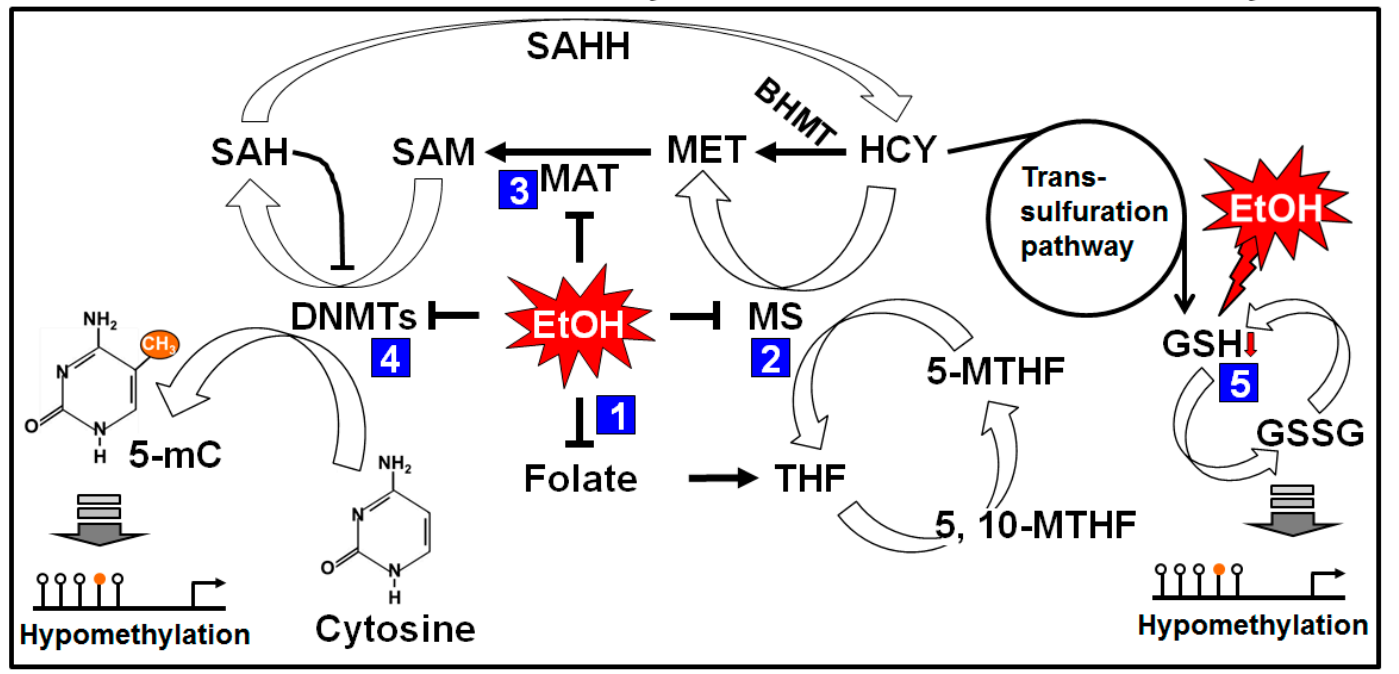

Figure 3. Effects of alcohol on one carbon metabolism and DNA methylation. Folic acid starts the folate cycle by converted itself to tetrahydrofolate (THF). THF is then converted to 5-methylene-THF (5-MTHF) to donate one carbon through the methylation of homocysteine (HCY) by methionine synthase (MS). The methionine cycle starts with the acceptation of the carbon from the folate cycle to form methionine (MET). S-adenosylmethionine (SAM) is formed from MET through the action of methionine adenyltransferase (MAT). SAM is further demethylated by donating the methyl group to Cytosine residue of DNA (in presence of DNMTs) and form S-adenosylhomocysteine (SAH). After deadenylation of SAH by S-adenosyl homocysteine hydrolase (SAHH), SAH is returned back to homocysteine and completes a full turn of the methionine cycle. HCY can also enter in to the transsulfuration pathway to form glutathione (GSH). Maternal heavy drinking reduces folate level (1), and cause inhibition of MS (2) and MAT (3), resulting low level of SAM. Reduction of SAM may cause induction of SAH which inhibits DNMTs (4) and causing global hypomethylation of DNA. Elevated HCY level produces GSH which is rapidly depleted by ethanol (5) and shifts the reaction from homocysteine cycle to transsulfuration pathway, causing further global hypomethylation of DNA. BHMT: betaine homocysteine methyltransferase.

Another important phenomenon of ethanol exposure is that it produces a high amount of ROS through the oxidative pathway of ethanol metabolism. Elevated ROS levels induce intracellular oxidative stress and can alter transcriptomic and epigenetic mechanisms involved in human carcinogenesis [36,37]. Gestational oxidative stress is responsible for alteration of fetal epigenetic patterns that can lead to cardiac disorders in neonatal subjects [38]. The main targets of ROS are the $\mathrm{CpGs}$ and the $\mathrm{CpG}$ islands near by the gene promoters. Oxidative stress causes oxidation of the methylated cytosine and/or guanine bases within the CpGs. Oxidation of the methylated cytosine base produces hydroxyl methylcytosine $(5-\mathrm{hmC})$ and this one is a pre-requisite for active demethylation [39]. Abnormal 5-hmC levels in cells may cause aberrant active DNA demethylation. On the other hand, oxidation of the guanine base produces 8-oxo deoxyguanosine (8-oxoG) which transforms methylated $\mathrm{CpG}$ islands to a more hydrophilic state to ease binding of transcription factors [40,41] (Figure 4). ROS-mediated oxidation of either methylated cytosine or guanine bases may cause hypomethylation of DNA and confer epigenetic regulation. This phenomenon is commonly found in neurodegenerative diseases [42] and seems to be the most clinically-associated consequence of high oxidative exposure [41]. Another circumstance of 8-oxoG formation is that it substantially diminishes methyl CpG binding-domain proteins (MBDs) binding when 8-oxoG is adjacent to the 5-mC and weakens the affinity bonding between DNA and DNMT3A, resulting in a reduced methylation status [43]. Furthermore, the unbound DNMT3A could result in random methylation of cytosine bases at non-CpG sites [44]. In cancer biology, ROS is associated with global hypomethylation and aberrant 
hypermethylation of some tumor suppressor gene promoters [45]. It was recently published that ROS can function as a catalyst that favors DNA methylation processes and caused hypermethylation of gene promoters [37]. Superoxide molecules are able to regulate DMNT functions as well [46]. When a superoxide molecule reacts with the C-5 atom it gets deprotonated sooner. On the other hand, after transferring the methyl group in SAM, it contains a positively-charged S-atom. Thus, it is possible to react with the nucleophilic C-5 atom and the charged S-atom to generate methylated cytosine. There is another possibility that the radical could react with another superoxide molecule to produce oxygen and hydroperoxyl [46]. In this way we can explain the ROS-mediated mechanism of DNA hypermethylation in promoter regions of targeted tumor suppression genes. Ethanol-mediated oxidation of guanine bases were first reported by Lia and Ohara [47] where they showed that the products of ethanol oxidation (1-hydroxyethyl and 2-hydroxyethyl radicals) were able to replace the C8 position of guanine and guanine bases in RNA and DNA [47]. A follow-up report was also published where they found the presence of C8-(1-hydroxyethyl) guanine in rat liver after ethanol exposure [48].

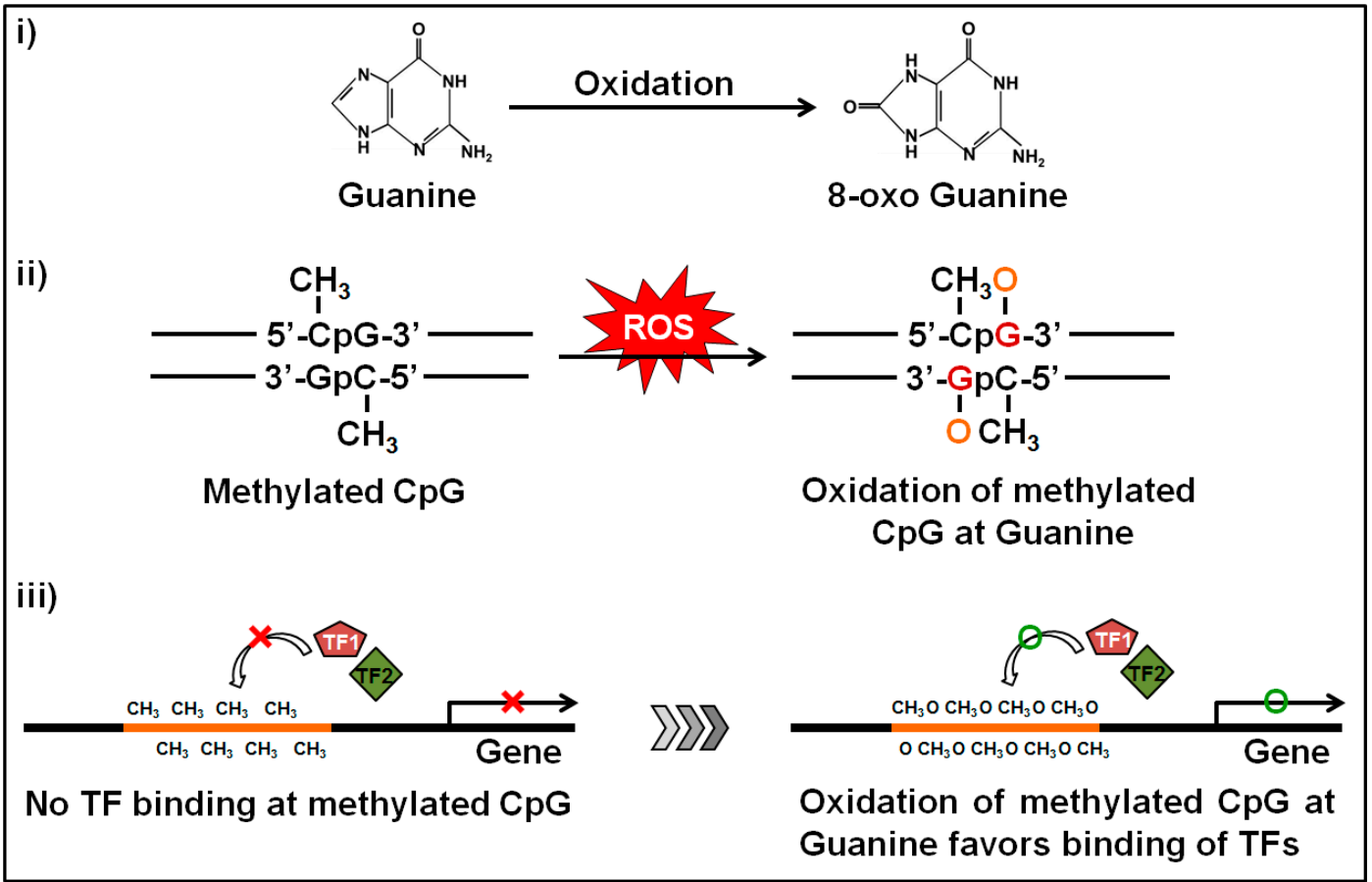

Figure 4. Oxidation of the methylated locus at guanine bases and subsequent impact. Guanine is the base that is more sensitive to oxidation. The oxidation produces 8-oxo deoxyguanosine from guanine and alters the structure of methylated CpGs. During oxidative stress, the methylated CpGs turns the promoter to a hydrophilic state by forming 8-oxo deoxyguanosine and facilitates the binding of transcription factors which in turn induces transcription of the related gene.

\section{Evidence of the Alteration of DNA Methylation by Alcohol in Utero}

Prenatal alcohol exposure was reported to cause altered expression of methyltransferase enzymes, and hypo- and hyper-methylation in gene promoters. The transient exposure of immature rodents to ethanol during postnatal day 7, comparable to a time point within the third trimester of human pregnancy, induces impaired DNA methylation by reducing the expression of two methyltransferase enzymes (DNMT1 and DNMT3A) [49]. Another report showed that administration of a low dose of ethanol to infant rats during the synaptogenesis period caused an induction of DNMT3A protein expression [50]. The craniofacial defects observed in FASD phenotypes of Japanese rice fish embryogenesis are the results of dysregulations in dnmt1 expression [51]. Prenatal binge alcohol exposure showed elevated mRNA levels of DNMT1, DNMT3B, and MeCP2 in the pituitary gland of 
fetal rats [52]. Not only are the expressions of methyltransferases altered, but the activity was also reduced significantly. Acute ethanol administration to pregnant mice produced fetuses that had lower levels of DNA methylase activity even in the presence of excess SAM $[53,54]$.

Alcohol-mediated changes in DNA methylation may affect multiple generations subsequent to alcohol exposure [54]. Children born with FASD have unique DNA methylation defects and are thought to adopt it from subsequent exposure to alcohol in utero $[55,56]$. Fetuses exposed to ethanol display hyper- and hypo-methylated CpGs which are related to neurodevelopmental process and diseases [19,57]. Neonatal alcohol exposure altered VGLUT2 gene expression in the adult hippocampus by reducing the methylation signature in its promoter [58]. Ethanol was found to hamper DNA methylation in a region of the brain known as the dentate gyrus, causing developmental retardation [59]. Recently, it was published that alcohol caused alterations of methylation profiles of two maternally-imprinted loci, KvDMR1 and PEG3 DMR, in a locus-specific manner [60]. Another report showed that ethanol had the ability to modulate the developmental rhythm of DNA methylation process during embryogenesis of Japanese rice fish [61]. Alcohol-mediated hypermethylation at the $A^{v y}$ locus in $A^{v y}$ heterozygous mice [62] and hypomethylation at the Igf2 locus in developing embryos [63] extended our knowledge about the ability of alcohol to alter developmentally-significant regions of the genome in an epigenetic manner. Bi-directional methylation changes were also reported by Liu et al. [64] who found that alcohol exposure caused neural tube defects through the alteration of DNA methylation (both hypomethylation and hypermethylation).

The similarity between epigenetic alterations mediated by alcohol and FASD etiology deserve further attention. Fetal alcohol exposure in the third trimester alters total DNA methylation in the murine hippocampus and prefrontal cortex [65]. Additionally, high throughput embryo analysis has shown that alcohol exposure alters the methylation pattern of more than one thousand genes involved in early neural development $[64,66]$. Zhou showed that alcohol inhibits the pathway by which moderately methylated genes become hypermethylated and hypomethylated, indicating the ability of alcohol to disrupt the methylation program of DNA [67]. A complete summary of altered methylome patterns by prenatal alcohol exposure is presented in Table 1.

In this review, we have discussed the effect of gestational alcohol exposure and subsequent alteration in fetal methylation patterns in the genomic DNA. There is another important phenomenon that exists regarding ethanol exposure which deals with the alteration of paternal sperm methylation. Though sperm methylation is not counted as a gestational event, but it is covered by the broad term "prenatal" [68]. Several reports are already published and have provided evidence that ethanol has specific effects on DMA methylation in sperm. The first report showed that intake of ethanol for nine weeks caused a reduction in DNMT1 expression in sperm [69]. In animal models, it was found that ethanol caused a significant decrease in DNA methylation at paternally-imprinted regions in sperm [70-72]. A similar result was also documented in humans which showed that men with moderate alcohol consumption caused reduced methylation patterns in paternally-imprinted regions in sperm [73]. To gain proper knowledge on alcohol-mediated alteration of sperm methylation, a global analysis of DNA methylation is required. 
Table 1. List of altered DNA methylation status by in utero ethanol exposure.

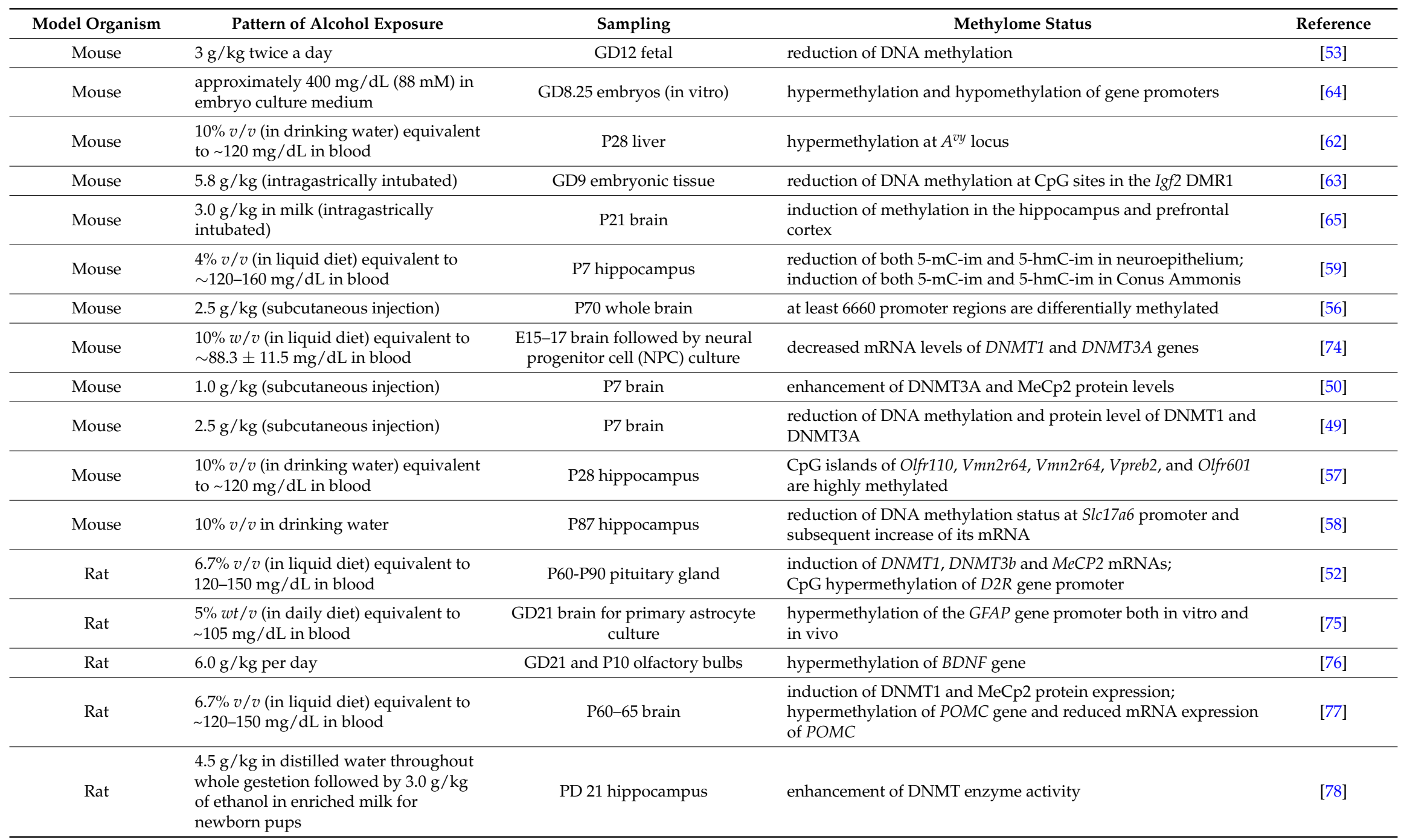


Table 1. Cont.

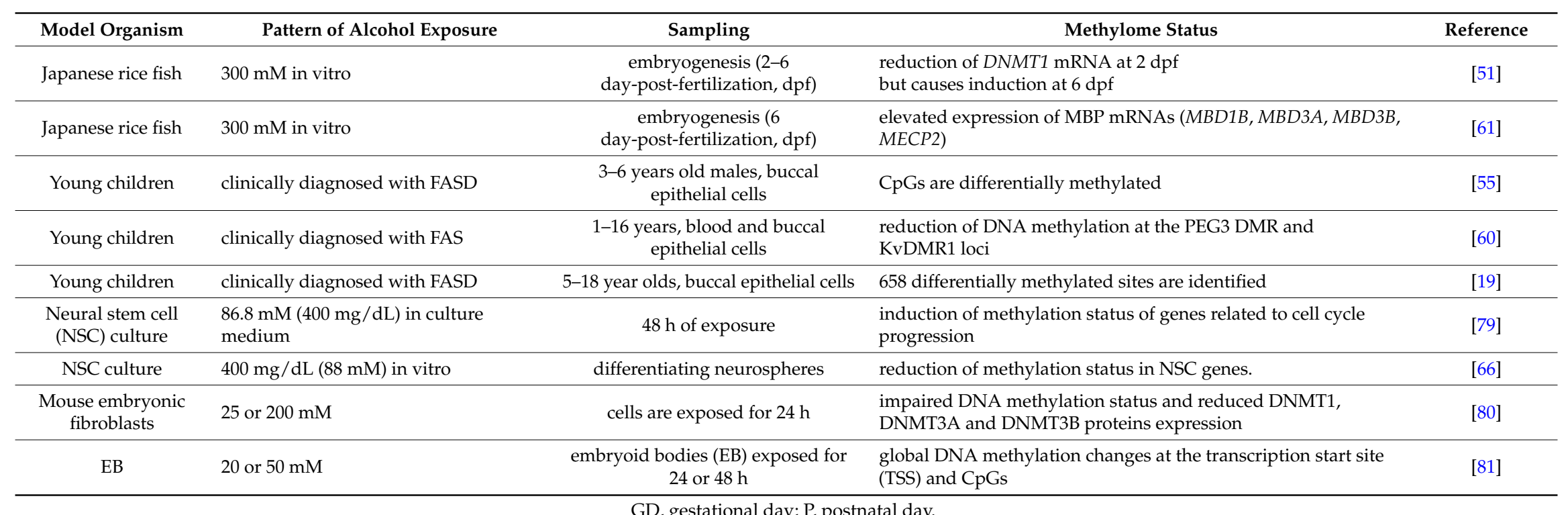

GD, gestational day; P, postnatal day. 


\section{Conclusions}

Maternal alcohol drinking may cause damage to the developing fetus in several aspects through direct and indirect manners. Researchers have identified various signaling pathways and molecular mechanisms which showed the mode of action of ethanol toxicity. However, the alteration of epigenetic mechanisms by ethanol is less well known. Researchers have started showing us the relevance of alcohol and DNA methylation from the last decade. The inhibition of one-carbon metabolism by ethanol is a vital path to suppression of DNA methyltransferase enzymes and the subsequent methylation status. We have gathered the known relationships between DNA methylation and ethanol-mediated teratogenesis, but additional study is needed to elucidate the correlation between these epigenetic changes and FASD.

Acknowledgments: This work was supported by National research foundation of Korea (NRF) funded by Korean Government under grant number 2011-0030049 to Young Gyu Chai.

Conflicts of Interest: The authors declare no conflict of interest.

\section{References}

1. Mandal, C.; Kim, S.H.; Chai, J.C.; Oh, S.M.; Lee, Y.S.; Jung, K.H.; Chai, Y.G. RNA sequencing reveals the alteration of the expression of novel genes in ethanol-treated embryoid bodies. PLOS ONE 2016, 11, e0149976. [CrossRef] [PubMed]

2. Mandal, C.; Halder, D.; Chai, J.C.; Lee, Y.S.; Jung, K.H.; Chai, Y.G. Profiling ethanol-targeted transcription factors in human carcinoma cell-derived embryoid bodies. Gene 2016, 576, 119-125. [CrossRef] [PubMed]

3. Halder, D.; Park, J.H.; Choi, M.R.; Chai, J.C.; Lee, Y.S.; Mandal, C.; Jung, K.H.; Chai, Y.G. Chronic ethanol exposure increases goosecoid (GSC) expression in human embryonic carcinoma cell differentiation. J. Appl. Toxicol. 2014, 34, 66-75. [CrossRef] [PubMed]

4. Mandal, C.; Park, J.H.; Lee, H.T.; Seo, H.; Chung, I.Y.; Choi, I.G.; Jung, K.H.; Chai, Y.G. Reduction of Nfia gene expression and subsequent target genes by binge alcohol in the fetal brain. Neurosci. Lett. 2015, 598, 73-78. [CrossRef] [PubMed]

5. Grewal, J.; Carmichael, S.L.; Ma, C.; Lammer, E.J.; Shaw, G.M. Maternal periconceptional smoking and alcohol consumption and risk for select congenital anomalies. Birth Defects Res. A Clin. Mol. Teratol. 2008, 82, 519-526. [CrossRef] [PubMed]

6. Bell, J.C.; Raynes-Greenow, C.; Turner, R.M.; Bower, C.; Nassar, N.; O'Leary, C.M. Maternal alcohol consumption during pregnancy and the risk of orofacial clefts in infants: A systematic review and meta-analysis. Paediatr. Perinat. Epidemiol. 2014, 28, 322-332. [CrossRef] [PubMed]

7. Mandal, C.; Park, K.S.; Jung, K.H.; Chai, Y.G. Ethanol-related alterations in gene expression patterns in the developing murine hippocampus. Acta Biochim. Biophys. Sin. 2015, 47, 581-587. [CrossRef] [PubMed]

8. Mandal, C.; Park, J.H.; Choi, M.R.; Kim, S.H.; Badejo, A.C.; Chai, J.C.; Lee, Y.S.; Jung, K.H.; Chai, Y.G. Transcriptomic study of mouse embryonic neural stem cell differentiation under ethanol treatment. Mol. Biol. Rep. 2015, 42, 1233-1239. [CrossRef] [PubMed]

9. Halder, D.; Mandal, C.; Lee, B.H.; Lee, J.S.; Choi, M.R.; Chai, J.C.; Lee, Y.S.; Jung, K.H.; Chai, Y.G. PCDHB14and GABRB1-like nervous system developmental genes are altered during early neuronal differentiation of NCCIT cells treated with ethanol. Hum. Exp. Toxicol. 2015, 34, 1017-1027. [CrossRef] [PubMed]

10. Sanchez-Alvarez, R.; Gayen, S.; Vadigepalli, R.; Anni, H. Ethanol diverts early neuronal differentiation trajectory of embryonic stem cells by disrupting the balance of lineage specifiers. PLoS ONE 2013, 8, e63794. [CrossRef] [PubMed]

11. Yao, B.; Christian, K.M.; He, C.; Jin, P.; Ming, G.L.; Song, H. Epigenetic mechanisms in neurogenesis. Nat. Rev. Neurosci. 2016, 17, 537-549. [CrossRef] [PubMed]

12. Goyama, S.; Kitamura, T. Epigenetics in normal and malignant hematopoiesis: An overview and update 2017. Cancer Sci. 2017, 108, 553-562. [CrossRef] [PubMed]

13. Holoch, D.; Moazed, D. RNA-mediated epigenetic regulation of gene expression. Nat. Rev. Genet. 2015, 16, 71-84. [CrossRef] [PubMed] 
14. Moosavi, A.; Ardekani, A.M. Role of epigenetics in biology and human diseases. Iran. Biomed. J. 2016, 20, 246-258. [PubMed]

15. Uysal, F.; Akkoyunlu, G.; Ozturk, S. Dynamic expression of DNA methyltransferases (DNMTs) in oocytes and early embryos. Biochimie 2015, 116, 103-113. [CrossRef] [PubMed]

16. Ziller, M.J.; Gu, H.; Muller, F.; Donaghey, J.; Tsai, L.T.; Kohlbacher, O.; de Jager, P.L.; Rosen, E.D.; Bennett, D.A.; Bernstein, B.E.; et al. Charting a dynamic DNA methylation landscape of the human genome. Nature 2013, 500, 477-481. [CrossRef] [PubMed]

17. Smith, Z.D.; Meissner, A. DNA methylation: Roles in mammalian development. Nat. Rev. Genet. 2013, 14, 204-220. [CrossRef] [PubMed]

18. Jones, P.A. Functions of DNA methylation: Islands, start sites, gene bodies and beyond. Nat. Rev. Genet. 2012, 13, 484-492. [CrossRef] [PubMed]

19. Portales-Casamar, E.; Lussier, A.A.; Jones, M.J.; MacIsaac, J.L.; Edgar, R.D.; Mah, S.M.; Barhdadi, A.; Provost, S.; Lemieux-Perreault, L.P.; Cynader, M.S.; et al. DNA methylation signature of human fetal alcohol spectrum disorder. Epigenetics Chromatin 2016, 9, 25. [CrossRef] [PubMed]

20. Reynes, B.; Palou, M.; Palou, A. Gene expression modulation of lipid and central energetic metabolism related genes by high-fat diet intake in the main homeostatic tissues. Food Funct. 2017, 8, 629-650. [CrossRef] [PubMed]

21. Ngai, Y.F.; Sulistyoningrum, D.C.; O’Neill, R.; Innis, S.M.; Weinberg, J.; Devlin, A.M. Prenatal alcohol exposure alters methyl metabolism and programs serotonin transporter and glucocorticoid receptor expression in brain. Am. J. Physiol. Regul. Integr. Comp. Physiol. 2015, 309, R613-R622. [CrossRef] [PubMed]

22. Rossi, R.E.; Conte, D.; Massironi, S. Diagnosis and treatment of nutritional deficiencies in alcoholic liver disease: Overview of available evidence and open issues. Dig. Liver Dis. 2015, 47, 819-825. [CrossRef] [PubMed]

23. Medici, V.; Halsted, C.H. Folate, alcohol, and liver disease. Mol. Nutr. Food Res. 2013, 57, 596-606. [CrossRef] [PubMed]

24. Young, J.K.; Giesbrecht, H.E.; Eskin, M.N.; Aliani, M.; Suh, M. Nutrition implications for fetal alcohol spectrum disorder. Adv. Nutr. 2014, 5, 675-692. [CrossRef] [PubMed]

25. Keating, E.; Lemos, C.; Goncalves, P.; Martel, F. Acute and chronic effects of some dietary bioactive compounds on folic acid uptake and on the expression of folic acid transporters by the human trophoblast cell line BeWo. J. Nutr. Biochem. 2008, 19, 91-100. [CrossRef] [PubMed]

26. Hutson, J.R.; Stade, B.; Lehotay, D.C.; Collier, C.P.; Kapur, B.M. Folic acid transport to the human fetus is decreased in pregnancies with chronic alcohol exposure. PLOS ONE 2012, 7, e38057. [CrossRef] [PubMed]

27. Keating, E.; Goncalves, P.; Campos, I.; Costa, F.; Martel, F. Folic acid uptake by the human syncytiotrophoblast: Interference by pharmacotherapy, drugs of abuse and pathological conditions. Reprod. Toxicol. 2009, 28, 511-520. [CrossRef] [PubMed]

28. Lee, T.D.; Sadda, M.R.; Mendler, M.H.; Bottiglieri, T.; Kanel, G.; Mato, J.M.; Lu, S.C. Abnormal hepatic methionine and glutathione metabolism in patients with alcoholic hepatitis. Alcohol Clin. Exp. Res. 2004, 28, 173-181. [CrossRef] [PubMed]

29. Farias, N.; Ho, N.; Butler, S.; Delaney, L.; Morrison, J.; Shahrzad, S.; Coomber, B.L. The effects of folic acid on global DNA methylation and colonosphere formation in colon cancer cell lines. J. Nutr. Biochem. 2015, 26, 818-826. [CrossRef] [PubMed]

30. Crider, K.S.; Yang, T.P.; Berry, R.J.; Bailey, L.B. Folate and DNA methylation: A review of molecular mechanisms and the evidence for folate's role. Adv. Nutr. 2012, 3, 21-38. [CrossRef] [PubMed]

31. Grillo, M.A.; Colombatto, S. S-adenosylmethionine and its products. Amino Acids 2008, 34, 187-193. [CrossRef] [PubMed]

32. Bonsch, D.; Lenz, B.; Fiszer, R.; Frieling, H.; Kornhuber, J.; Bleich, S. Lowered DNA methyltransferase (DNMT-3b) mRNA expression is associated with genomic DNA hypermethylation in patients with chronic alcoholism. J. Neural Transm. 2006, 113, 1299-1304. [CrossRef] [PubMed]

33. Diaz-Vivancos, P.; de Simone, A.; Kiddle, G.; Foyer, C.H. Glutathione-Linking cell proliferation to oxidative stress. Free Radic. Biol. Med. 2015, 89, 1154-1164. [CrossRef] [PubMed] 
34. Lu, S.C.; Huang, Z.Z.; Yang, H.; Mato, J.M.; Avila, M.A.; Tsukamoto, H. Changes in methionine adenosyltransferase and S-adenosylmethionine homeostasis in alcoholic rat liver. Am. J. Physiol. Gastrointest. Liver Physiol. 2000, 279, G178-G185. [PubMed]

35. Mytilineou, C.; Kramer, B.C.; Yabut, J.A. Glutathione depletion and oxidative stress. Parkinsonism Relat. Disord. 2002, 8, 385-387. [CrossRef]

36. Ziech, D.; Franco, R.; Pappa, A.; Panayiotidis, M.I. Reactive oxygen species (ROS)-Induced genetic and epigenetic alterations in human carcinogenesis. Mutat. Res. 2011, 711, 167-173. [CrossRef] [PubMed]

37. Wu, Q.; Ni, X. ROS-mediated DNA methylation pattern alterations in carcinogenesis. Curr. Drug Targets 2015, 16, 13-19. [CrossRef] [PubMed]

38. Avila, J.G.; Echeverri, I.; de Plata, C.A.; Castillo, A. Impact of oxidative stress during pregnancy on fetal epigenetic patterns and early origin of vascular diseases. Nutr. Rev. 2015, 73, 12-21. [CrossRef] [PubMed]

39. Guo, J.U.; Su, Y.; Zhong, C.; Ming, G.L.; Song, H. Hydroxylation of 5-methylcytosine by TET1 promotes active DNA demethylation in the adult brain. Cell 2011, 145, 423-434. [CrossRef] [PubMed]

40. Menezo, Y.; Dale, B.; Cohen, M. DNA damage and repair in human oocytes and embryos: A review. Zygote 2010, 18, 357-365. [CrossRef] [PubMed]

41. Dattilo, M.; Giuseppe, D.; Ettore, C.; Menezo, Y. Improvement of gamete quality by stimulating and feeding the endogenous antioxidant system: Mechanisms, clinical results, insights on gene-environment interactions and the role of diet. J. Assist. Reprod. Genet. 2016, 33, 1633-1648. [CrossRef] [PubMed]

42. Wu, J.; Basha, M.R.; Brock, B.; Cox, D.P.; Cardozo-Pelaez, F.; McPherson, C.A.; Harry, J.; Rice, D.C.; Maloney, B.; Chen, D.; et al. Alzheimer's disease (AD)-like pathology in aged monkeys after infantile exposure to environmental metal lead $(\mathrm{Pb})$ : Evidence for a developmental origin and environmental link for AD. J. Neurosci. 2008, 28, 3-9. [CrossRef] [PubMed]

43. Valinluck, V.; Tsai, H.H.; Rogstad, D.K.; Burdzy, A.; Bird, A.; Sowers, L.C. Oxidative damage to methyl-CpG sequences inhibits the binding of the methyl-CpG binding domain (MBD) of methyl-CpG binding protein 2 (MeCP2). Nucleic Acids Res. 2004, 32, 4100-4108. [CrossRef] [PubMed]

44. Menezo, Y.J.; Silvestris, E.; Dale, B.; Elder, K. Oxidative stress and alterations in DNA methylation: Two sides of the same coin in reproduction. Reprod. Biomed. Online 2016, 33, 668-683. [CrossRef] [PubMed]

45. Lim, S.O.; Gu, J.M.; Kim, M.S.; Kim, H.S.; Park, Y.N.; Park, C.K.; Cho, J.W.; Park, Y.M.; Jung, G. Epigenetic changes induced by reactive oxygen species in hepatocellular carcinoma: Methylation of the E-cadherin promoter. Gastroenterology 2008, 135, 2128-2140. [CrossRef] [PubMed]

46. Afanas'ev, I. New nucleophilic mechanisms of ROS-dependent epigenetic modifications: Comparison of aging and cancer. Aging Dis. 2013, 5, 52-62. [CrossRef] [PubMed]

47. Nakao, L.S.; Augusto, O. Nucleic acid alkylation by free radical metabolites of ethanol. Formation of 8-(1-hydroxyethyl)guanine and 8-(2-hydroxyethyl)guanine adducts. Chem. Res. Toxicol. 1998, 11, 888-894. [CrossRef] [PubMed]

48. Nakao, L.S.; Fonseca, E.; Augusto, O. Detection of C8-(1-hydroxyethyl)guanine in liver RNA and DNA from control and ethanol-treated rats. Chem. Res. Toxicol. 2002, 15, 1248-1253. [CrossRef] [PubMed]

49. Nagre, N.N.; Subbanna, S.; Shivakumar, M.; Psychoyos, D.; Basavarajappa, B.S. CB1-receptor knockout neonatal mice are protected against ethanol-induced impairments of DNMT1, DNMT3A, and DNA methylation. J. Neurochem. 2015, 132, 429-442. [CrossRef] [PubMed]

50. Subbanna, S.; Nagre, N.N.; Shivakumar, M.; Umapathy, N.S.; Psychoyos, D.; Basavarajappa, B.S. Ethanol induced acetylation of histone at G9a exon1 and G9a-mediated histone H3 dimethylation leads to neurodegeneration in neonatal mice. Neuroscience 2014, 258, 422-432. [CrossRef] [PubMed]

51. Dasmahapatra, A.K.; Khan, I.A. DNA methyltransferase expressions in Japanese rice fish (Oryzias latipes) embryogenesis is developmentally regulated and modulated by ethanol and 5-azacytidine. Comp. Biochem. Physiol. C Toxicol. Pharmacol. 2015, 176, 1-9. [CrossRef] [PubMed]

52. Gangisetty, O.; Wynne, O.; Jabbar, S.; Nasello, C.; Sarkar, D.K. Fetal alcohol exposure reduces dopamine receptor D2 and increases pituitary weight and prolactin production via epigenetic mechanisms. PLoS ONE 2015, 10, e0140699. [CrossRef] [PubMed]

53. Garro, A.J.; McBeth, D.L.; Lima, V.; Lieber, C.S. Ethanol consumption inhibits fetal DNA methylation in mice: Implications for the fetal alcohol syndrome. Alcohol Clin. Exp. Res. 1991, 15, 395-398. [CrossRef] [PubMed]

54. Mead, E.A.; Sarkar, D.K. Fetal alcohol spectrum disorders and their transmission through genetic and epigenetic mechanisms. Front. Genet. 2014, 5, 154. [CrossRef] [PubMed] 
55. Laufer, B.I.; Kapalanga, J.; Castellani, C.A.; Diehl, E.J.; Yan, L.; Singh, S.M. Associative DNA methylation changes in children with prenatal alcohol exposure. Epigenomics 2015, 7, 1259-1274. [CrossRef] [PubMed]

56. Laufer, B.I.; Mantha, K.; Kleiber, M.L.; Diehl, E.J.; Addison, S.M.; Singh, S.M. Long-lasting alterations to DNA methylation and ncRNAs could underlie the effects of fetal alcohol exposure in mice. Dis. Model. Mech. 2013, 6, 977-992. [CrossRef] [PubMed]

57. Marjonen, H.; Sierra, A.; Nyman, A.; Rogojin, V.; Grohn, O.; Linden, A.M.; Hautaniemi, S.; Kaminen-Ahola, N. Early maternal alcohol consumption alters hippocampal DNA methylation, gene expression and volume in a mouse model. PLoS ONE 2015, 10, e0124931. [CrossRef] [PubMed]

58. Zhang, C.R.; Ho, M.F.; Vega, M.C.; Burne, T.H.; Chong, S. Prenatal ethanol exposure alters adult hippocampal VGLUT2 expression with concomitant changes in promoter DNA methylation, H3K4 trimethylation and miR-467b-5p levels. Epigenetics Chromatin 2015, 8, 40. [CrossRef] [PubMed]

59. Chen, Y.; Ozturk, N.C.; Zhou, F.C. DNA methylation program in developing hippocampus and its alteration by alcohol. PLoS ONE 2013, 8, e60503. [CrossRef] [PubMed]

60. Masemola, M.L.; van der Merwe, L.; Lombard, Z.; Viljoen, D.; Ramsay, M. Reduced DNA methylation at the PEG3 DMR and KvDMR1 loci in children exposed to alcohol in utero: A South African fetal alcohol syndrome cohort study. Front. Genet. 2015, 6, 85. [CrossRef] [PubMed]

61. Dasmahapatra, A.K.; Khan, I.A. Modulation of DNA methylation machineries in Japanese rice fish (Oryzias latipes) embryogenesis by ethanol and 5-azacytidine. Comp. Biochem. Physiol. C Toxicol. Pharmacol. 2016, 179, 174-183. [CrossRef] [PubMed]

62. Kaminen-Ahola, N.; Ahola, A.; Maga, M.; Mallitt, K.A.; Fahey, P.; Cox, T.C.; Whitelaw, E.; Chong, S. Maternal ethanol consumption alters the epigenotype and the phenotype of offspring in a mouse model. PLoS Genet. 2010, 6, e1000811. [CrossRef] [PubMed]

63. Downing, C.; Johnson, T.E.; Larson, C.; Leakey, T.I.; Siegfried, R.N.; Rafferty, T.M.; Cooney, C.A. Subtle decreases in DNA methylation and gene expression at the mouse igf2 locus following prenatal alcohol exposure: Effects of a methyl-supplemented diet. Alcohol 2011, 45, 65-71. [CrossRef] [PubMed]

64. Liu, Y.; Balaraman, Y.; Wang, G.; Nephew, K.P.; Zhou, F.C. Alcohol exposure alters DNA methylation profiles in mouse embryos at early neurulation. Epigenetics 2009, 4, 500-511. [CrossRef] [PubMed]

65. Otero, N.K.; Thomas, J.D.; Saski, C.A.; Xia, X.; Kelly, S.J. Choline supplementation and DNA methylation in the hippocampus and prefrontal cortex of rats exposed to alcohol during development. Alcohol Clin. Exp. Res. 2012, 36, 1701-1709. [CrossRef] [PubMed]

66. Zhou, F.C.; Balaraman, Y.; Teng, M.; Liu, Y.; Singh, R.P.; Nephew, K.P. Alcohol alters DNA methylation patterns and inhibits neural stem cell differentiation. Alcohol Clin. Exp. Res. 2011, 35, 735-746. [CrossRef] [PubMed]

67. Zhou, F.C. DNA methylation program during development. Front. Biol. 2012, 7, 485-494. [CrossRef] [PubMed]

68. Finegersh, A.; Rompala, G.R.; Martin, D.I.; Homanics, G.E. Drinking beyond a lifetime: New and emerging insights into paternal alcohol exposure on subsequent generations. Alcohol 2015, 49, 461-470. [CrossRef] [PubMed]

69. Bielawski, D.M.; Zaher, F.M.; Svinarich, D.M.; Abel, E.L. Paternal alcohol exposure affects sperm cytosine methyltransferase messenger RNA levels. Alcohol Clin. Exp. Res. 2002, 26, 347-351. [CrossRef] [PubMed]

70. Knezovich, J.G.; Ramsay, M. The effect of preconception paternal alcohol exposure on epigenetic remodeling of the H19 and Rasgrf1 imprinting control regions in mouse offspring. Front. Genet. 2012, 3, 10. [CrossRef] [PubMed]

71. Liang, F.; Diao, L.; Liu, J.; Jiang, N.; Zhang, J.; Wang, H.; Zhou, W.; Huang, G.; Ma, D. Paternal ethanol exposure and behavioral abnormities in offspring: Associated alterations in imprinted gene methylation. Neuropharmacology 2014, 81, 126-133. [CrossRef] [PubMed]

72. Finegersh, A.; Homanics, G.E. Paternal alcohol exposure reduces alcohol drinking and increases behavioral sensitivity to alcohol selectively in male offspring. PLoS ONE 2014, 9, e99078. [CrossRef] [PubMed]

73. Ouko, L.A.; Shantikumar, K.; Knezovich, J.; Haycock, P.; Schnugh, D.J.; Ramsay, M. Effect of alcohol consumption on CPG methylation in the differentially methylated regions of H19 and IG-DMR in male gametes: Implications for fetal alcohol spectrum disorders. Alcohol Clin. Exp. Res. 2009, 33, 1615-1627. [CrossRef] [PubMed] 
74. Tyler, C.R.; Allan, A.M. Prenatal alcohol exposure alters expression of neurogenesis-related genes in an ex vivo cell culture model. Alcohol 2014, 48, 483-492. [CrossRef] [PubMed]

75. Valles, S.; Pitarch, J.; Renau-Piqueras, J.; Guerri, C. Ethanol exposure affects glial fibrillary acidic protein gene expression and transcription during rat brain development. J. Neurochem. 1997, 69, 2484-2493. [CrossRef] [PubMed]

76. Maier, S.E.; Cramer, J.A.; West, J.R.; Sohrabji, F. Alcohol exposure during the first two trimesters equivalent alters granule cell number and neurotrophin expression in the developing rat olfactory bulb. J. Neurobiol. 1999, 41, 414-423. [CrossRef]

77. Bekdash, R.A.; Zhang, C.; Sarkar, D.K. Gestational choline supplementation normalized fetal alcohol-induced alterations in histone modifications, DNA methylation, and proopiomelanocortin (POMC) gene expression in $\beta$-endorphin-producing POMC neurons of the hypothalamus. Alcohol Clin. Exp. Res. 2013, 37, 1133-1142. [CrossRef] [PubMed]

78. Perkins, A.; Lehmann, C.; Lawrence, R.C.; Kelly, S.J. Alcohol exposure during development: Impact on the epigenome. Int. J. Dev. Neurosci. 2013, 31, 391-397. [CrossRef] [PubMed]

79. Hicks, S.D.; Middleton, F.A.; Miller, M.W. Ethanol-induced methylation of cell cycle genes in neural stem cells. J. Neurochem. 2010, 114, 1767-1780. [CrossRef] [PubMed]

80. Mukhopadhyay, P.; Rezzoug, F.; Kaikaus, J.; Greene, R.M.; Pisano, M.M. Alcohol modulates expression of DNA methyltranferases and methyl $\mathrm{CpG}-/ \mathrm{CpG}$ domain-binding proteins in murine embryonic fibroblasts. Reprod. Toxicol. 2013, 37, 40-48. [CrossRef] [PubMed]

81. Khalid, O.; Kim, J.J.; Kim, H.S.; Hoang, M.; Tu, T.G.; Elie, O.; Lee, C.; Vu, C.; Horvath, S.; Spigelman, I.; et al. Gene expression signatures affected by alcohol-induced DNA methylomic deregulation in human embryonic stem cells. Stem Cell Res. 2014, 12, 791-806. [CrossRef] [PubMed]

(C) 2017 by the authors. Licensee MDPI, Basel, Switzerland. This article is an open access article distributed under the terms and conditions of the Creative Commons Attribution (CC BY) license (http://creativecommons.org/licenses/by/4.0/). 